This PDF is a selection from a published volume from the National Bureau of Economic Research

Volume Title: International Financial Issues in the Pacific Rim: Global Imbalances, Financial Liberalization, and Exchange Rate Policy (NBER-EASE Volume 17)

Volume Author/Editor: Takatoshi Ito and Andrew K. Rose, editors

Volume Publisher: The University of Chicago Press

Volume ISBN: 0-226-38682-1

Volume URL: http://www.nber.org/books/ito_08-1

Conference Dates: June 22-24, 2006

Publication Date: July 2008

Chapter Title: Financial Liberalization under the WTO and Its Relationship with the Macro Economy

Chapter Author: Lee-Rong Wang, Chung-Hua Shen, Ching-Yang Liang

Chapter URL: http://www.nber.org/chapters/c6987

Chapter pages in book: (315 - 345) 


\title{
Financial Liberalization under the WTO and Its Relationship with the Macro Economy
}

\author{
Lee-Rong Wang, Chung-Hua Shen, and \\ Ching-Yang Liang
}

\subsection{Introduction}

The effect of financial liberalization on growth has recently attracted a significant amount of attention. Financial liberalization, through giving banks and other financial intermediaries more freedom of action, results in resources being governed by the market mechanism and hence being more efficiently allocated. Three broad types of financial liberalization are discussed. One is concerned with lifting the restrictions on the domestic financial sector, which includes the deregulation of the interest rate, the exchange rate, allowing new financial instruments to be introduced, and encouraging mergers among financial institutions, to name but a few. Demirgüç-Kunt and Detragiache (2001) have chosen the deregulation of bank interest rates as the centerpiece of financial liberalization. MontesNegret and Landa (2001) study the Mexican financial process.

The second broad liberalization concerns the opening up of the domestic market to international participants, that is, allowing the domestic market to be parallel to the international one. Claessens and Glaessner (1998) point out that internationalization has helped build more robust and efficient financial systems by introducing international practices and standards, by allowing more stable sources of funds, and by improving the quality, efficiency, and breadth of financial services. Claessens, Demirgüç-

Lee-Rong Wang is a research fellow in the Taiwan WTO Center at the Chung-Hua Institution for Economic Research. Chung-Hua Shen is a professor in the Department of Finance at National Taiwan University. Ching-Yang Liang is a Ph.D. student in the Department of Public Finance at National Chengchi University.

This paper was prepared for the NBER 17th Annual East Asian Seminar on Economics held at the Mauna Lani Bay Hotel, 68-1400 Mauna Lani Drive, Kohala, Hawaii on June 22-24, 2006. 
Kunt, and Huizinga (2001) study the effects of foreign bank entry on the efficiency of domestic banks. The experiences of various countries seem to suggest that a foreign bank presence can facilitate increased competition, improve the allocation of credit, and help increase access to international capital markets. Henry (2000) and Beakers and Harvey (2000) show that the liberalization of equity markets, through a reduction in the cost of capital, leads to an increase in real economic growth on an annual basis.

The third approach is to construct a financial liberalization index on the basis of the World Trade Organization (WTO) commitments. The members of the General Agreement on Tariffs and Trade (GATT), the predecessor of the WTO, ${ }^{1}$ commenced bilateral negotiations on services in 1994 and have started to submit liberalization commitments and schedules since then. Each member, in considering its own domestic situation, has progressively liberalized its trade in services according to these schedules.

There are twelve sectors covered in the services negotiation under the WTO; we focus particularly on the largest one, the financial services sector. For each subsector of financial services, each country promises three types of commitment: unbound (no commitment), bound (partial commitment), and none (full commitment). By employing the commitments data as of mid-1994, Hoekman $(1995,1996)$ uses values of $0,0.5$, and 1 to enumerate the above three kinds of commitments, with a higher number denoting a higher degree of liberalization. They use this frequency measures method to quantify the impediments to trade and investment in services, which are less transparent and more difficult to quantify.

The first purpose of this chapter is to extend and improve the method suggested by Hoekman $(1995,1996)$ in calculating the financial liberalization indices. However, we make several revisions. The first revision is concerned with covering the services supply mode ${ }^{2}$ that deals with the movement/presence of natural persons and all sub-sectors listed in the Annex on Financial Services. The second revision is to employ weighting on four modes of services supply. The last revision, instead of unanimously giving a 0.5 score to the partial commitments as Hoekman $(1995,1996)$ and Hoekman and Primo Braga (1997) did, is intended to analyze in more detail the information involved within different degrees of liberalization and thus score further on the partial commitments.

1. The WTO began life on January 1, 1995, but its trading system is half a century older. Since 1948, the GATT has provided the rules for the system. The last and largest GATT round was the Uruguay Round, which lasted from 1986 to 1994 and led to the WTO's creation. Whereas the GATT dealt mainly with trade in goods, the WTO and its agreements now cover trade in services, in the context of the General Agreement on Trade in Services (GATS), and other areas.

2. The GATS distinguishes the ways in which services are supplied into four possible modes, which are listed as cross-border supply (Mode 1), consumption abroad (Mode 2), commercial presence (Mode 3), and the presence of natural persons (Mode 4). Section 10.2 of this chapter will further explain these modes. 
The second purpose of this chapter is to study the effect of liberalization on economic growth. By employing our newly-constructed financial index, we investigate the effects of liberalization on economic growth. In the literature, the different spheres of liberalization are threefold, namely, trade, financial, and equity liberalization. For studies using the trade liberalization as the proxy for liberalization, Francois and Schuknecht (1999), who employ the openness in trade, find a strong positive relationship between growth and competition within the financial sector. Eschenbach, Francois, and Schuknecht (2000) also place emphasis on the procompetitive effects of trade in financial services. Since financial services are the nexus of the savings and accumulation mechanism that drives economic growth, they consider it appropriate to emphasize trade in services and growth. By working with a cross-country sample of ninety-three countries, Tornell, Westerman, and Martinez (2004) have recently found that trade liberalization enhances growth but that financial liberalization does not necessarily lead to more rapid growth, in large part because it is associated with risky capital flows, lending booms, and crises. With regard to financial liberalization, Demirgüç-Kunt and Detragiache (1998) find that financial liberalization has a very large and statistically significant effect on the probability of a banking crisis. Shen and Lee (2006), in using the liberalization dates suggested by Kaminsky and Reinhert (2002), find that the liberalization has little effect on the relationship between financial development and economic growth. Finally, for studies using equity liberalization, Henry (2000) reports that equity liberalization has preceded private investment booms in nine of eleven developed countries. Although they discuss a slightly different issue, Kawakatsu and Morey (1999) reject the hypothesis that market liberalization affects the economy. There is no research that uses the WTO liberalization index to study the same issue.

The remainder of this chapter is organized as follows. Section 10.2 introduces the history of WTO commitments and describes how we construct the financial liberalization index. Section 10.3 discusses some interesting patterns of the financial liberalization under the WTO. Section 10.4 describes the empirical models and data, while section 10.5 presents the empirical findings. Finally, section 10.6 summarizes the conclusions that are drawn.

\subsection{WTO Commitments and the Liberalization Index for Financial Services}

\subsubsection{Introduction to WTO Commitments for Financial Services}

The construction of a financial liberalization index in our chapter is based on the negotiation results within the WTO. The WTO requests that member countries negotiate with each other on the liberalization of trade 
in goods, trade in services, and trade-related intellectual property rights. ${ }^{3}$ This chapter deals only with the second category, that is, trade in services. There are twelve sectors that are included in these services and we particularly focus on the financial services sector, which is the largest service sector in the context of the General Agreement on Trade in Services (GATS). Furthermore, this service sector can be categorized into two major subsectors, one being the banking and other financial services subsector and the other the insurance and insurance-related services subsector. In our chapter, the negotiation results within the WTO for both subsectors are taken into account when the financial liberalization index is constructed.

The GATS negotiations on trade in services have so far gone through two stages. The first stage started in 1994 and continued until 2000, whereas the second started in 2001 and extended through 2006. During the first period, the critical part of the GATS negotiations that was referred to as "specific commitments" in regard to the liberalization schedules, was submitted by the WTO members beginning in 1994 .

After that, the first round of negotiations on financial services in the context of the GATS was concluded in December 1997 and became fully subject to multilateral trade rules. Some members, nevertheless, did not provide their liberalization schedules until 2000 for the sake of their domestic situation. Not only did the agreement consolidate the relatively open policies of industrial countries that account for much of the world trade in financial services, but it also evoked wide participation from both developing countries and countries in transition. The wide coverage of the WTO members is the reason why, in this chapter, we build the financial liberalization index based on the GATS commitments.

The next round of negotiations to further liberalize trade in services started March 28, 2001, when the WTO Council for Trade in Services adopted the Guidelines and Procedures for the Negotiations as the basis for continuing the negotiations. Participants were to submit requests and offers for specific commitments by certain deadlines. However, as the request and offer negotiations continued among WTO members, the contents of the specific commitments also continued to be updated until 2006. As a result, our data for financial liberalization and the coordinating macroeconomic data are classified into the two periods, as previously shown.

The GATS also distinguishes ways of categorizing supply into four possible modes, which are listed as cross-border supply (mode 1), ${ }^{4}$ consump-

3. These three parts are stipulated under the General Agreement on Tariffs and Trade (GATT), the General Agreement on Trade in Services (GATS), and Trade Related Intellectual Property Rights (TRIPS), respectively.

4. Under the mode for cross-border supply, the services suppliers and consumers remain in their own domestic territories, while tackling the trading business between them via the Internet or through the use of other electronic tools, such as facsimiles. 
tion abroad (mode 2), ${ }^{5}$ commercial presence (mode 3), ${ }^{6}$ and the movement of natural persons (mode 4). One example of financial services in mode 1 is buying overseas mutual funds via the Internet. Buying insurance in a foreign country when a person travels abroad is an example of mode 2. As for mode 3, the worldwide Citi-Group branch establishments would be a typical case. Sending intracorporate transferees to one specific branch is a mode 4 . Basically, modes 1, 2, and 4 are all different forms of cross-border trade, whereas mode 3 generally involves investment (foreign direct investment) in the service-importing economy.

It is interesting to explore, at least to some degree, how the GATS commitments relate to actual liberalization measures in the real world. The extent of the new liberalization effected by GATS commitments on financial services is somewhat limited, with many members binding either at the level of their existing practices or at a level lower than their existing practices (PECC International Secretariat 2003). In the latter cases, GATS commitments (the de jure indication) were a misleading indicator of the extent to which liberalization had actually taken place (the de facto indicators). There are reasons for WTO members choosing to have this kind of situation. The WTO commitment schedule is legally binding for all members. Strict dispute settlement procedures will be initiated by members whenever their benefits are impeded once the commitment schedule is not followed by a certain member or members. To avoid the legal constraints mentioned above, some members would end up having their GATS commitments no more favorable than the real regulation.

Besides, recognizing the benefits of liberalizing trade in services has encouraged a number of economies, including some in the APEC region such as Korea, Singapore, and Taiwan, to undertake unilateral liberalization in this sector. Subsequent unilateral liberalization by some members has widened the gap between GATS commitments and actual measures. The credit for such autonomous liberalization is currently an important negotiating issue for those economies that have engaged in it (PECC International Secretariat 2003).

\subsubsection{Construction of the Financial Liberalization Index}

Our liberalization index is constructed by using the commitments of the four modes within various subsectors of financial services. As mentioned in the Introduction, three types of commitments, unbound (no commitment), bound (partial commitment), and none (full commitment), are promised by each country. Because the impediments to trade and invest-

5. Consumption abroad keeps services suppliers in their own domestic territory, while consumers move into the territory of the services suppliers and proceed to trade there.

6. Commercial presence keeps services consumers in their own domestic territory, while suppliers move into the territory of the consumers and proceed to trade there. 
ment in services tend to be in the form of nontariff barriers (NTBs), which are less transparent and difficult to quantify, researchers often adopt the frequency measures method. ${ }^{7}$ PECC (1995), Hoekman $(1995,1996)$, and Hoekman and Primo Braga (1997) are among the seminal studies to employ the frequency measures methodology to compile indices of services to measure the degree of restrictiveness or liberalization of trade in services. McGuire and Schuele (2000) also propose a restrictiveness index ${ }^{8}$ for banking services and compile a list of nonprudential regulations on entry and operations for banking services from various sources. These sources include the GATS commitments, the information from APEC Individual Action Plans, WTO Trade Policy Reviews, and information provided by several countries to the IMF as a requirement for receiving standby credit facilities. Mattoo $(1998,2000)$ constructs commitment indices for the Second Protocol using a specific weighting scheme, considering the importance of modes (based on U.S. data) for 105 countries' market access commitments in banking (deposits and lending) and direct insurance (life and nonlife). Mattoo, Rathindran, and Subramanian (2006) present a financial index of openness to quantify the nature and extent of restrictions on international trade in financial services.

The estimates of the measures for the liberalization of services trade in the previous literature, however, contain several shortcomings. Our chapter revises the previously produced financial liberalization index in three respects. First, we cover mode 4 and all subsectors listed in the "Annex on Financial Services" of the GATS. Then we assign weights for the four modes. Finally, and most importantly, we score partial commitments, which are ignored in earlier works. These three major types of revisions are accounted for below.

First, our liberalization index covers mode 4, which is the movement of natural persons. Except for Hoekman (1995, 1996), McGuire and Schuele (2000), and Claessens and Glaessner (1998), who cover only some parts of mode 4 , past studies typically do not take this mode into account. ${ }^{9}$ The criteria for scoring the liberalization index and the categories for mode 4 are listed in table 10.1, where higher scores denote higher degrees of liberalization. The two extreme cases, "unbound" (no commitment) and "none" (full commitment), are assigned scores of 0 and 1, respectively. Partial commitments are here assigned scores from 0.25 to 0.75 , depending on the respective degrees of openness as described in table 10.1.

7. This is also referred to as index methodology.

8. McGuire and Schuele (2000) use higher scores to denote higher degrees of restriction, whereas we use higher scores to denote higher degrees of liberalization. In other words, the restrictiveness index produced in McGuire and Schuele (2000) is similar to our liberalization index in terms of the concept, yet opposite in terms of the content's meaning.

9. For example, Barth, Caprio, and Levine (2001), Mattoo (1998, 2000), and Mattoo, Rathindran, and Subramanian (2006) do not take mode 4 into account. 
Table 10.1

Scoring liberalization index for M4

The Criteria

Score

Unbound

(1) Only referring to general requirements for entry, including the economic need test (ENT) or making reference to laws and regulations

(2) Conditionally allowing the entry of $1 \sim 2$ kinds of the above-mentioned natural persons

(1) Unconditionally allowing the entry of 2 kinds of the above-mentioned natural persons

(2) Conditionally allowing the entry of $3 \sim 4$ kinds of the above-mentioned natural persons

Unconditionally allowing the entry of 4 kinds of the above-mentioned natural persons 0.75

None

Note: This paper computes these scores based on the classification summarized in the WTO document (JOB[03]/195), which describes frequently-used categories of natural persons included under mode 4 in the horizontal section of members' schedules of specific commitments. The four main categories are intracorporate transferees (ICT), business visitors (BV) and service salespersons (SS), contractual service suppliers (CSS) and other categories. CSS includes employees of juridical persons and independent professionals. Other categories contain graduate trainees and spouses and partners of ICT.

This chapter also takes into account all of the subsectors covered in the context of the GATS. ${ }^{10}$ By contrast, Claessens and Glaessner (1998), Mattoo $(1998,2000)$, and McGuire and Schuele (2000) ${ }^{11}$ do not cover the subsectors as completely as we do here.

The second revision concerns the weighting of the four modes. Most countries do not provide a precise identification of the patterns of trade based on different modes, ${ }^{12}$ except the United States. Therefore, previous studies often use a simple-weighted average. By considering that commitments with heavier amounts trade should be assigned more weight, we therefore follow Mattoo's $(1998,2000)$ method to adopt the data from the United States Financial Services Trade by Mode of Supply, 1994. Mattoo (1998, 2000), however, does not include mode 4 and covers only parts of the subsectors. ${ }^{13}$ We therefore make some revisions to his approach and present the final weight in table 10.2. After our revisions, the trade that takes place as a result of the commercial presence in the insurance subsector is about four times that generated through across-border trade. In banking

10. These subsectors are listed in the Annex on Financial Services of the GATS.

11. For instance, McGuire and Schuele (2000) cover only the banking subsector.

12. Maurer (2005) reported the weights for the four modes as $0.35,0.12-0.15,0.5$, and 0.01-0.02, respectively. However, these figures are derived on an aggregated level and cover all of the service sectors.

13. Mattoo $(1998,2000)$ covers only life and nonlife insurance in the insurance subsector, and deposits and lending in the banking subsector, as shown in table 10.2. 


\begin{tabular}{|c|c|c|c|c|c|c|}
\hline \multirow[b]{3}{*}{ Mode } & \multicolumn{3}{|c|}{$\begin{array}{c}\text { All Insurance and } \\
\text { Insurance-Related Services }\end{array}$} & \multicolumn{3}{|c|}{ Banking and Other Financial Services } \\
\hline & \multicolumn{2}{|c|}{ Mattoo $(1998,2000)$} & \multirow[b]{2}{*}{$\begin{array}{l}\text { Weights adopted } \\
\text { by the authors }\end{array}$} & \multicolumn{2}{|c|}{ Mattoo $(1998,2000)$} & \multirow[b]{2}{*}{$\begin{array}{l}\text { Weights adopted } \\
\text { by the authors }\end{array}$} \\
\hline & $\begin{array}{c}\text { Life } \\
\text { Services }\end{array}$ & $\begin{array}{l}\text { Non-life } \\
\text { Services }\end{array}$ & & $\begin{array}{l}\text { Deposits } \\
\text { Services }\end{array}$ & $\begin{array}{l}\text { Lending } \\
\text { Services }\end{array}$ & \\
\hline Mode 1 & 0.12 & 0.20 & 0.18 & 0.12 & 0.20 & 0.24 \\
\hline Mode 2 & 0.03 & 0.05 & 0.045 & 0.03 & 0.05 & 0.06 \\
\hline Mode 3 & 0.85 & 0.75 & 0.75 & 0.85 & 0.75 & 0.6 \\
\hline Mode 4 & - & - & 0.025 & - & - & 0.1 \\
\hline
\end{tabular}

Note: According to Article I of the GATS, the four modes of the supply of a service are defined as: Mode 1 (cross-border supply) - the supply of a service from the territory of one member into the territory of any other member; Mode 2 (consumption abroad) - the supply of a service in the territory of one member to the service consumer of any other member; Mode 3 (commercial presence) - the supply of a service by a service supplier of one member, through commercial presence in the territory of any other member; Mode 4 (the movement/presence of natural persons) - the supply of a service by a service supplier of one member, through the presence of natural persons of a member in the territory of any other member.

and securities services, the trade arising through the commercial presence is two and a half times that achieved through the cross-border trade.

Finally, partial commitments are scored. Due to the difficulty in judging how the presence of specific restrictions is to be evaluated, Hoekman $(1995,1996)$ assigned a score of 0.5 for each partial commitment. Although this method has its merits in that it is simple and straightforward, the information resulting from different degrees of liberalization has been lost. Mattoo $(1998,2000)$ adopts a slightly more sophisticated approach, but only handles the commitments in relation to mode 3. Qian (2000) and Valckx (2002) also adopt the same method. Furthermore, Valckx (2002) believes that the unbound feature is slightly better than a blank entry, and hence the score 0.05 is given instead of 0 . Valckx (2002) also gives licensing subject to requirements a slightly higher score than discretionary licensing, in order to make a distinction between the two limitations. This chapter employs the formula proposed by Switzerland (TN/S/W/51, September 2005) to deal with this issue more delicately.

Our methodology of scoring partial commitments deserves description. As suggested by Switzerland, each member's specific commitments are entered according to an arithmetic formula (continuous function) referred to as the formula $C^{n}$, where $C$ denotes any coefficient between 0 and 1, and superscript $n$ denotes the number of scheduled restrictions in one entry. For practical purposes, the coefficient $C$ is set at 0.5 , although it could be any number given that it equally applies to all schedules. ${ }^{14}$ The formula is

14. The value of the coefficient is not of particular relevance since comparability across commitments and members lies at the heart of the exercise. 
based on two considerations. First, each limitation to market access and/or national treatment is an additional burden for the service supplier (or consumer). Therefore, an accurate and reliable methodology has to allow barriers to trade for every scheduled limitation to be tracked. Second, it is assumed that the marginal burden that falls on the service supplier due to an additional limitation is decreasing.

For simplicity, this chapter counts the number of scheduled restrictions affecting market access and national treatment according to the classification specified in Bosworth et al. (2000). Besides the classification specified in Article XVI of the GATS, ${ }^{15}$ Bosworth et al. (2000) add one more measure affecting market access, "other" to avoid missing any other kinds of restrictions.

\subsection{Interesting Patterns of the Financial Liberalization under the WTO}

After the construction of the financial liberalization index based on GATS commitments, we highlight seven important patterns.

First, as can be seen in table 10.3, the degree of liberalization of financial services over the 2001-2006 period is overall higher than that during the 1994-2000 period. The low income countries and high income non-OECD countries have improved the most among the five income level groups. High income non-OECD countries are observed to have improved a great deal, especially in the subsector for insurance and insurance-related services.

Second, a member with a high degree of liberalization in one of these two subsectors in financial services tends to have a high degree of liberalization in the other subsector. This is because the correlation of the liberalization indices between the insurance industry and the banking-and-others industry is 70.04 percent during the period $1994-2000$, and is also 71.03 percent during 2001-2006.

Third, under modes 1,2 and 3, the degree of liberalization in relation to market access is positively correlated with the income level; however, there is no such link under mode 4 . This is probably because mode 4 is related to the natural persons and because developing countries have abundant labor resources; thus, developing countries promote liberalization under mode 4 the most. By contrast, developed countries are modest in terms of liberal-

15. The classification of the scheduled restrictions specified in Bosworth, Findlay, Trewin, and Warren (2000) is as follows: (a) measures affecting market access include limitations on the number of service suppliers, limitations on the total value of service transactions or assets, limitations on the total number of service operations or on the total quantity of service outputs, limitations on the total number of natural persons that may be employed in a sector, measures which restrict or require specific types of legal entity or joint venture, limitations on the participation of foreign capital, and other measures affecting market access; (b) measures affecting national treatment include discriminatory taxes, discriminatory incentives/subsidies, government procurement policies, local content requirements, nationality, citizenship or residence requirements, and other measures affecting national treatment. 
Comparison of the liberalization index of financial services in the two periods of 1994-2000 and 2001-2006 classified by income level

\begin{tabular}{|c|c|c|c|c|c|}
\hline Income Level & $\begin{array}{l}\text { No. of } \\
\text { Countries }\end{array}$ & $\begin{array}{c}\text { Time } \\
\text { Period } / \% \\
\text { of Change }\end{array}$ & $\begin{array}{c}\text { All Insurance } \\
\text { and } \\
\text { Insurance-related } \\
\text { Services }\end{array}$ & $\begin{array}{c}\text { Banking } \\
\text { and Other } \\
\text { Financial } \\
\text { Services }\end{array}$ & $\begin{array}{c}\text { All } \\
\text { Financial } \\
\text { Services }\end{array}$ \\
\hline \multirow{3}{*}{$\begin{array}{l}\text { High income } \\
\text { OECD countries }\end{array}$} & \multirow[t]{3}{*}{24} & 1994-2000 & 0.6904 & 0.7173 & 0.7038 \\
\hline & & 2001-2006 & 0.7584 & 0.7763 & 0.7674 \\
\hline & & $\%$ of change & 9.85 & 8.23 & 9.04 \\
\hline \multirow{3}{*}{$\begin{array}{l}\text { High income } \\
\text { Non-OECD } \\
\text { countries }\end{array}$} & \multirow[t]{3}{*}{13} & 1994-2000 & 0.4821 & 0.432 & 0.4571 \\
\hline & & 2001-2006 & 0.6364 & 0.4708 & 0.5536 \\
\hline & & $\%$ of change & 32.01 & 8.98 & 21.11 \\
\hline \multirow{3}{*}{$\begin{array}{l}\text { Upper-middle } \\
\text { income countries }\end{array}$} & \multirow[t]{3}{*}{25} & 1994-2000 & 0.4947 & 0.4569 & 0.4758 \\
\hline & & 2001-2006 & 0.5625 & 0.4577 & 0.5101 \\
\hline & & $\%$ of change & 13.71 & 0.18 & 7.21 \\
\hline \multirow{3}{*}{$\begin{array}{l}\text { Low-middle } \\
\text { income countries }\end{array}$} & \multirow[t]{3}{*}{27} & 1994-2000 & 0.4428 & 0.3625 & 0.4027 \\
\hline & & 2001-2006 & 0.4708 & 0.3761 & 0.4235 \\
\hline & & $\%$ of change & 6.32 & 3.75 & 5.17 \\
\hline \multirow{3}{*}{$\begin{array}{l}\text { Low income } \\
\text { countries }\end{array}$} & \multirow[t]{3}{*}{4} & 1994-2000 & 0.2658 & 0.233 & 0.2494 \\
\hline & & 2001-2006 & 0.3319 & 0.2852 & 0.3086 \\
\hline & & $\%$ of change & 24.87 & 22.40 & 23.74 \\
\hline
\end{tabular}

Notes: High income OECD countries include Australia, Austria, Belgium, Canada, Denmark, Finland, France, Germany, Greece, Iceland, Ireland, Italy, Japan, Korea, Luxembourg, the Netherlands, New Zealand, Norway, Portugal, Spain, Sweden, Switzerland, the United Kingdom, and the United States. High income non-OECD countries include Bahrain, Brunei, Cyprus, Hong Kong, Israel, Liechtenstein, Macao, Malta, Qatar, Singapore, Slovenia, Taiwan, and United Arab Emirates. Upper-middle income countries include Argentina, Barbados, Chile, Costa Rica, Croatia, the Czech Republic, Dominica, Estonia, Gabon, Grenada, Hungary, Latvia, Lithuania, Malaysia, Mauritius, Mexico, Panama, Poland, the Slovak Republic, Saint Kitts and Nevis, Saint Lucia, Saint Vincent and the Grenadines, Trinidad and Tobago, Uruguay, and Oman. Low-middle income countries include Albania, Bolivia, Brazil, Bulgaria, China, Colombia, Cuba, Dominican Republic, Egypt, El Salvador, Fiji, Guatemala, Guyana, Honduras, Indonesia, Jamaica, Jordan, Macedonia, Morocco, Paraguay, Peru, the Philippines, Sri Lanka, Suriname, Thailand, Tunisia, and Turkey. Low income countries include India, Kenya, Nicaragua, and Pakistan. Weights among the four modes are the same as those adopted by the authors in 10.2 .

izing under mode 4 and focus more on the issues of improving transparency and procedures related to the movement of natural persons.

Fourth, we compare the performance of liberalization across the four modes. Higher income members ${ }^{16}$ have, on average, the highest level of market access liberalization under mode 2 . Considering the difficulty involved in regulating consumption abroad, many WTO members therefore choose to liberalize the market access under mode 2. However, with regard to the national treatment part, mode 3 appears to have the highest degree of liberalization regardless of the income level.

Furthermore, it is found in table 10.4, in which countries are classified by

16. These include high income OECD countries, high income non-OECD countries, and upper-middle income countries. 


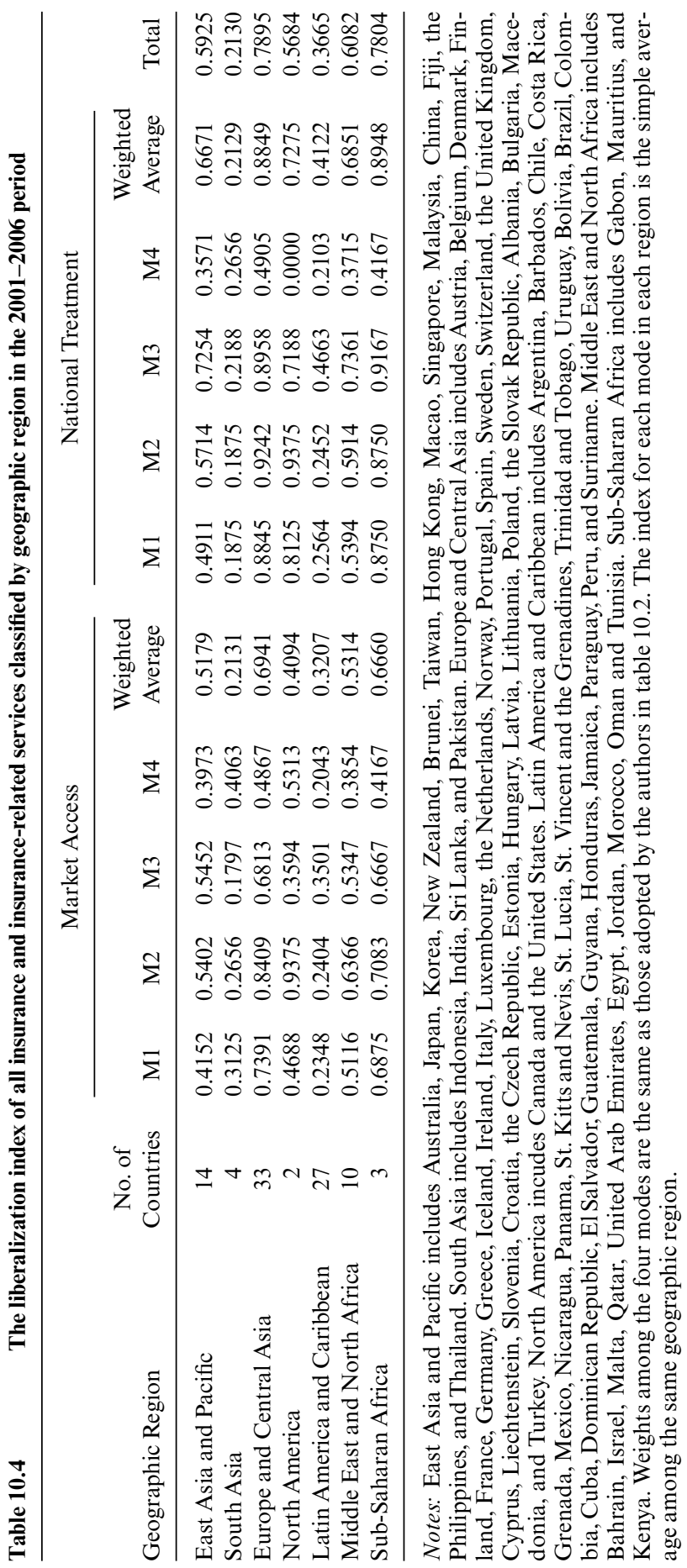


geographic region, that East Asia and the Pacific, and Latin America and the Caribbean liberalize mode 3 the most in the insurance and insurancerelated services subsector. On the other hand, Europe and Central Asia, the Middle East and North Africa, and North American countries choose to liberalize less under mode 3 compared to modes 1 and 2 . The degree of liberalization in the banking and other financial services subsector under mode 3 for East Asia and the Pacific region, though not the highest, still remains high among the four modes, as shown in table 10.5. East Asia and the Pacific, and Latin American and the Caribbean regions comprise many developing countries, which attract experienced foreign financial institutions through foreign direct investment (i.e., mode 3 ) that in a great way help develop their own domestic financial industries. Due to the liberalization in relation to mode 3 , and by attracting much incoming foreign direct investment, these countries not only enhance industrial development and technology transfer, but also raise their domestic employment in these areas. Mode 3, as a result, is traditionally the most popular liberalization mode for the governments in these regions.

Under the WTO, commitments to liberalize mode 1 of a service oblige a member to allow the necessary capital movements. To reduce the chances of the occurrence of a financial crisis facilitated by capital movements, many WTO members therefore choose to liberalize mode 1 as little as possible. Compared with other regions, European and Central Asian and North American (except for the insurance subsector) countries have a higher degree of liberalization in regard to mode 1, as shown in table 10.4 and table 10.5. Does this have anything to do with their performance in the trade in financial services or with the occurrence of financial crises? The next two patterns would be a good, yet preliminary, kickoff for examining this issue. From table 10.4 and table 10.5, we find that some regions have similar liberalization performances across different subsectors, but that some regions do not. In the former cases, East Asia and the Pacific region ranks fourth and Europe and the Central Asia region ranks first in both subsectors. By contrast, the financial liberalization in North America and the SubSaharan African regions is very different in the different subsectors. For instance, North America is the second most liberal region in regards to the banking and other financial services subsector, whereas it only ranks as the fifth most liberal region in relation to the insurance and insurance-related services subsector. The degree of liberalization in North America in the latter subsector surprisingly lags behind many other less developed regions, such as East Asia and Pacific and the Sub-Saharan Africa regions.

Finally, we examine the correlation between the financial liberalization index and the trade balance (i.e., the current account) of financial services for ninety-three WTO members. It is found in table 10.6 that, regardless of the subsectors, the liberalization index has a higher degree of correlation with the total trade balance (i.e., exports plus imports) than the net trade 


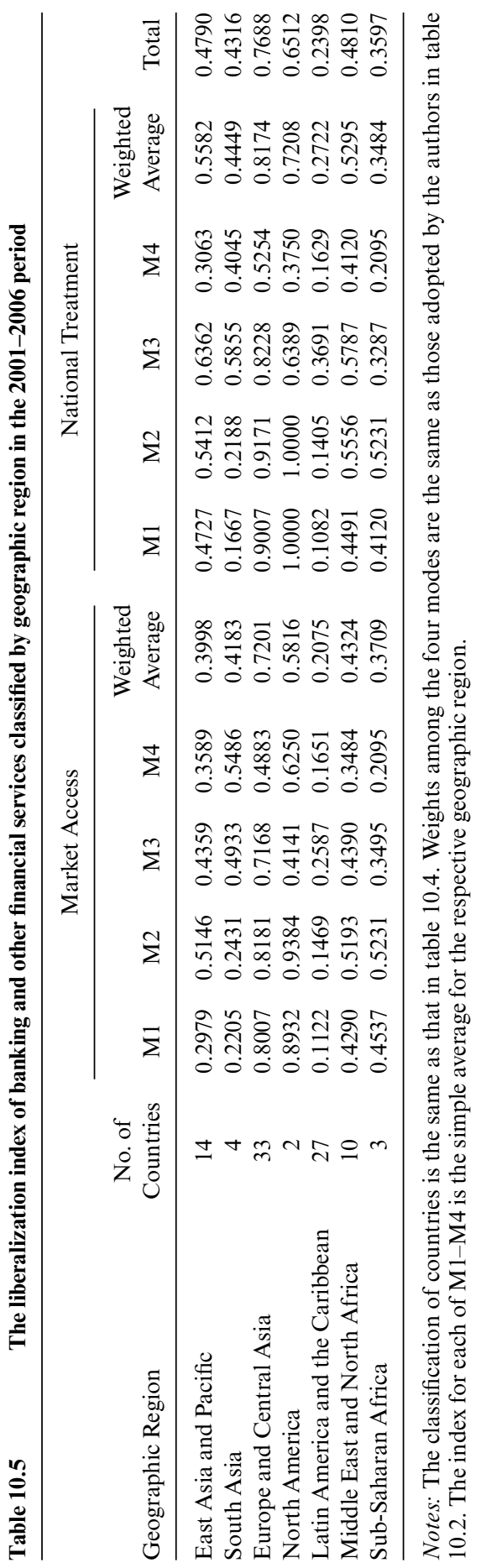


Table 10.6 The relationship (correlation coefficient) between the financial liberalization index and the trade balance (current account) of financial services for WTO members

\begin{tabular}{llcc}
\hline Sub-sectors & \multicolumn{1}{c}{ Trade Balance } & $\begin{array}{c}\text { Weights adopted } \\
\text { by the authors }\end{array}$ & $0.8 * \mathrm{M} 1+0.2 * \mathrm{M} 2$ \\
\hline Insurance services & Net Trade Balance & 0.102965 & 0.276626 \\
& Total Trade Balance & 0.137906 & 0.150024 \\
Banking and other services & Net Trade Balance & 0.094380 & 0.179390 \\
& Total Trade Balance & 0.306151 & 0.377653 \\
Financial services & Net Trade Balance & 0.154236 & 0.294957 \\
& Total Trade Balance & 0.270827 & 0.328254 \\
\hline
\end{tabular}

balance (i.e., exports minus imports). The net trade balance, theoretically speaking, should be more closely connected with each member's exchange rate and competitiveness in their respective areas. The existing current account statistics for services from the IMF, however, do not cover the trading volume defined by mode 3 and mode 4 . It is therefore more reasonable to consider only the degree of liberalization for mode 1 and mode 2 when examining this issue. The liberalization index that is composed of only mode 1 and mode 2 (with 0.8 and 0.2 weights, respectively) is further established to explore the above relationship. As shown in the last column of table 10.6, the correlation between the liberalization index and both trade balances, respectively, is raised when only mode 1 and mode 2 are covered. Again, the liberalization index for overall financial services has a higher degree of correlation with the total trade balance than with the net trade balance.

\subsection{Econometric Model}

This section specifies the relationship between financial liberalization and macroeconomic performance, which is measured in terms of the average growth rate for per capita GDP for the periods 1994-2000 and 2001-2006, respectively. By employing a similar model to that in Eschenbach, Francois, and Schuknecht (2000), our model is, Model (A):

$$
\begin{aligned}
\text { PCGDPGR }_{I}= & a_{0}+a_{1} \text { COMMITTOBANK }_{i} \\
& +a_{2} \text { CONCENTRATION }_{i}+a_{3} \text { CREDIT }_{i}+a_{4} \text { TRADE }_{i} \\
& +a_{5} \text { STDINFLA }_{i}+a_{6} \text { PCGDPOO }_{i} \\
& +a_{7} \text { SECOND }_{i}+a_{8} \text { INSTITUTION }_{i} \\
& +a_{9} \text { POPGR } \varepsilon_{i}
\end{aligned}
$$

(2) CONCENTRATION ${ }_{j}=b_{0}+b_{1}$ COMMITTOBANK $_{j}+b_{2} \operatorname{SIZE}_{j}+\varepsilon_{j}$ 
Model (B):

(1) PCGDPGR PCa $_{i}+a_{1}$ CONCENTRATION $_{i}+a_{2}$ CREDIT $_{i}$

$$
\begin{aligned}
& +a_{3} T_{R A D E}+a_{4} \text { STDINFL }_{i}+a_{5} \text { PCGDP90 }_{i} \\
& +a_{6} \text { SECOND90 }_{i}+a_{7} \text { INSTITUTION }_{i} \\
& +a_{8} P O P G R_{i}+\varepsilon_{i}
\end{aligned}
$$

(2) CONCENTRATION ${ }_{j}=b_{0}+b_{1}$ COMMITTOBANK ${ }_{j}+b_{2} S_{Z} E_{j}+\varepsilon_{j}$

Model (C):

$$
\begin{aligned}
\text { PCGDPGR }_{i}= & a_{0}+a_{1} \text { COMMITTOALL }_{i}+a_{2} \text { COMMITTOALL }_{i}^{2} \\
& +a_{3} \text { CONCENTRATION } \\
& +a_{5} \text { TRADEDIT }_{i}+a_{6} \text { STDINFLA }_{i}+a_{7} \text { PCGDP90 }_{i} \\
& +a_{8} \text { SECOND90 }_{i}+a_{9} \text { INSTITUTION }_{i}+\varepsilon_{i}
\end{aligned}
$$

Model (D):

$$
\begin{aligned}
\text { PCGDPGR }_{i}= & a_{0}+a_{1} \text { COMMITTOBANK } \\
& +a_{2} \text { CONCENTRATION }+a_{3} \text { CREDIT }_{i} \\
& +a_{4} \text { TRADE }_{i}+a_{2} \text { STDINFLA }_{i}+a_{6} \text { PCGDPO }_{i} \\
& +a_{7} \text { SECOND90 }_{i}+a_{8} \text { INSTITUTION }_{i}+a_{9} \text { POPGR }_{i} \\
& +a_{10} \text { INVESTMENT }_{i}+\varepsilon_{i}
\end{aligned}
$$

(2) CONCENTRATION CON $_{j}+b_{1}$ COMMITTOBANK ${ }_{j}+b_{2} S_{I Z E_{i}}+\varepsilon_{j}$

(3) $a_{1}=c_{0}+c_{1}$ GOVERNANCE $+c_{2}$ REGION;

where COMMITTOBANK is the constructed liberalization index described in the previous section; CONCENTRATION is the concentration ratio of the banking sector, which is the sum of the market shares (measured in total assets) of the three largest banks in a country; CREDIT is the private credit to total credit; TRADE depicts the trade openness, which is the sum of exports and imports divided by GDP; STDINFLA is the standard deviation of the inflation rate; $P C G D P 90$ is the per capita GDP in 1990, which is the proxy for the initial endowment; SECOND90 denotes the primary school enrollment and secondary school enrollment ratio in 1990; SIZE is included because, as discussed in Francois and Schuknecht (1999), larger markets can imply more scope for competition, particularly if scale economies are present.

There are two vectors of conditional variables in Model (D). The first vector of variables is GOVERNANCE, which contains five government governance variables. The first one is GOVEFFECT, which denotes government effectiveness and regulatory quality taken from Kaufmann, Kraay, and Mastruzzi (2005, hereafter KKZ). Next, SUPERVISION, which denotes the official supervisory power, examines whether the supervisory authorities possess the power to take corrective action when confronted with violations of regulations or other imprudent behavior on the 
part of banks. The larger the number, the more the authority has the power to supervise the banks. The variable is taken from Barth, Caprio, and Levine (2006). Third, PRIVATEMONITOR denotes the private monitoring index, which is also taken from Barth, Caprio, and Levine (2006). It means that bank behavior is affected by private market forces and the greater the figure, the more the public has access to information regarding the overall condition of the banking industry. Fourth, CAPITALREGU, which is the capital regulatory index and is taken from Barth, Caprio, and Levine (2006), examines whether there are explicit regulatory requirements regarding the amount of capital. Last, INSTITUTION denotes the corruption, law and order, and bureaucracy quality, which is taken from the International Country Risk Guide (ICRG).

The second set REGION includes three regional dummies, which are EASIA, denoting the dummy variable for the East Asian and Pacific countries; LATIN, denoting the dummy variable for the Latin American and Caribbean countries; and SAHARAN, denoting the dummy variable for the Sub-Saharan African countries. Detailed definitions and sources of these and other variables are reported in table 10.7.

The four models can be accounted for as follows. Model (A) investigates the direct and indirect links between banking liberalization and economic growth. If there is a direct impact, COMMITTOBANK in equation (1) will have a positive effect on growth and $a_{1}$ is significant. If there is an indirect impact, COMMITTOBANK should have a negative effect on CONCEN$T R A T I O N$, which also has a negative effect on growth. This suggests that $a_{2}$ and $b_{1}$ are negative.

Model (B) is similar to Model (A) but does not consider the direct effect by taking COMMITTOBANK out of equation (1). Thus, only the indirect link between banking liberalization and economic growth is examined, whereas the effects related to trade in financial services are then subsumed into the CONCENTRATION term.

Model (C) is opposite to Model (B) in that it only explores the direct relationship between the total financial liberalization and economic growth. Thus, the variable COMMITTOALL appears in equation (1), and equation (2) is removed. The concept can also be found in Mattoo, Rathindran, and Subramanian (2006), where the term COMMITTOBANK is replaced by the term COMMITTOALL to take into account the impact of liberalization of the financial subsectors overall.

In contrast to the above three models, where the impact of COMMITTOBANK is constant, Model (D) permits the direct impacts to be influenced by the two sets of variables, GOVERNANCE and REGION. As suggested by Shen and Lee (2006), good governance should strengthen the impact of liberalization. We do not have priors regarding the impacts of the regional effects.

The control variables in the four models are similar to those reported in 


\begin{tabular}{|c|c|}
\hline Variable Name & Description \\
\hline$P C G D P G R$ & $\begin{array}{l}\text { The average of the per capita growth rate over the respective } \\
1994-2000 \text { and } 2001-2006 \text { periods }\end{array}$ \\
\hline СОММITTOBANK & $\begin{array}{l}\text { Score on the index of financial liberalization calculated from } \\
\text { each WTO member's GATS commitments in financial } \\
\text { services (excluding insurance). }\end{array}$ \\
\hline СОММITTOALL & $\begin{array}{l}\text { Score on the index of financial liberalization calculated from } \\
\text { each WTO member's GATS commitments in financial } \\
\text { services (including insurance). }\end{array}$ \\
\hline$C O N C E N T R A T I O N$ & $\begin{array}{l}\text { Concentration in the financial sector: the assets of the } 3 \text { largest } \\
\text { banks as a share of total assets expressed as a percentage, } \\
\text { averaged over 1994-2000 and 2001-2006, respectively. }\end{array}$ \\
\hline$C R E D I T$ & $\begin{array}{l}\text { Credit to the private sector as a percentage of total credit, } \\
\text { averaged over the periods } 1994-2000 \text { and } 2001-2006 \text {, } \\
\text { respectively. }\end{array}$ \\
\hline$T R A D E$ & $\begin{array}{l}\text { Trade openness, exports plus imports over GDP, averaged } \\
\text { over the periods } 1994-2000 \text { and } 2001-2006 \text {, respectively. }\end{array}$ \\
\hline STDINFLA & $\begin{array}{l}\text { The standard deviation of the inflation rate over the } \\
\text { respective 1994-2000 and 2001-2006 periods. }\end{array}$ \\
\hline$P C G D P 90$ & Per capita GDP in 1990. \\
\hline SECOND90 & $\begin{array}{l}\text { The primary school enrollment and secondary school } \\
\text { enrollment ratio in } 1990 .\end{array}$ \\
\hline INSTITUTION & $\begin{array}{l}\text { General conditions of corruption, law and order, and } \\
\text { bureaucratic quality (from Political Risk Services), ranging } \\
\text { from } 0 \text { to } 6 \text {, where } 6 \text { is the best, averaged over the periods } \\
1994-2000 \text { and } 2001-2006 \text {, respectively. }\end{array}$ \\
\hline$P O P G R$ & $\begin{array}{l}\text { Average rate of population growth over the periods } 1994- \\
2000 \text { and 2001-2006. }\end{array}$ \\
\hline INVESTMENT & $\begin{array}{l}\text { Gross capital formation as a percentage of GDP, averaged } \\
\text { over the periods } 1994-2000 \text { and } 2001-2006 \text {, respectively. }\end{array}$ \\
\hline$S I Z E$ & $\begin{array}{l}\text { Total value of GDP as a percentage of world GDP, averaged } \\
\text { over the periods } 1994-2000 \text { and } 2001-2006 \text {, respectively. }\end{array}$ \\
\hline SUPERVISION & $\begin{array}{l}\text { Official supervisory power, which examines whether the } \\
\text { supervisory authorities possess the power to take corrective } \\
\text { action when confronted with violations of regulations or other } \\
\text { imprudent behavior on the part of banks. This variable ranges } \\
\text { from } 0 \text { to 14, with a higher value indicating greater power. }\end{array}$ \\
\hline PRIVATEMONITOR & $\begin{array}{l}\text { The private monitor index, which tries to capture market or } \\
\text { private monitoring existing in different countries. The greater } \\
\text { the number, the more the public has access to information } \\
\text { about the overall condition of the banking industry. This } \\
\text { variable ranges from } 0 \text { to } 9 \text { with a higher value indicating } \\
\text { more supervision. }\end{array}$ \\
\hline
\end{tabular}

Source

WDI and IFS

Constructed

by authors

Constructed

by authors

BDL

WDI and IFS

WDI and IFS

WDI and IFS

WDI and IFS

WDI

ICRG

WDI and IFS

WDI

WDI and IFS

BCL

BCL

(continued) 
Table 10.7

(continued)

\begin{tabular}{|c|c|c|}
\hline Variable Name & Description & Source \\
\hline CAPITALREGU & $\begin{array}{l}\text { The conditions of overall capital stringency and initial capital } \\
\text { stringency. It captures both the amount of capital and } \\
\text { verifiable sources of capital that a bank is required to possess. } \\
\text { This variable ranges from } 0 \text { to } 9 \text { with a higher value indicating } \\
\text { greater stringency. }\end{array}$ & $\mathrm{BCL}$ \\
\hline GOVEFFECT & $\begin{array}{l}\text { The conditions of government effectiveness and regulatory } \\
\text { quality. Government effectiveness combines responses on the } \\
\text { quality of public service provisions, the quality of the bureau- } \\
\text { cracy, the competence of civil servants, the independence of } \\
\text { the civil service from political pressures, and the credibility of } \\
\text { the government's commitment to policies. Regulatory quality } \\
\text { instead focuses more on the policies themselves, including } \\
\text { measures of the incidence of market-unfriendly policies such } \\
\text { as price controls or inadequate bank supervision, as well as } \\
\text { perceptions of the burdens imposed by excessive regulation in } \\
\text { areas such as foreign trade and business development. }\end{array}$ & KKZ \\
\hline EASIA & East Asian and Pacific countries $=1$, otherwise $=0$. & WDI \\
\hline LATIN & Latin American and Caribbean countries $=1$, otherwise $=0$. & WDI \\
\hline SAHARAN & Sub-Saharan African countries $=1$, otherwise $=0$. & WDI \\
\hline
\end{tabular}

Notes: WDI: World Development Indicators, published by the World Bank. IFS: International Financial Statistics, published by the IMF. BDL: Beck, Demirgüç-Kunt and Levine (2000). ICRG: International Country Risk Guide, published by the PRS Group. BCL: Barth, Caprio, and Levine (2006). KKZ: Kaufmann, Kraay, and Mastruzzi (2005).

Eschenbach et al. (2000), Levine and Zervos (1998), and Shen and Lee (2006). For example, CREDIT describes the role of financial development in the growth equation, TRADE controls the effect of trade openness, $S T D I N F L A$ reflects the uncertainty of inflation on the growth, $P C G D P 90$ serves as the initial endowment effect, SECOND90 is schooling levels, and INSTITUTION is institutional factors (measures of corruption, law and order, and bureaucratic quality), as well as population growth over the two periods.

Country size is measured by GDP, and scaled by world GDP. We employ the share of domestic banking assets held by the three largest banks to measure the degree of competition in banking. ${ }^{17}$

17. The concentration ratio is an outcome-based variable, and, moreover, a misleading indicator of the level of competition in the banking system because a concentrated market for banking services can still be contestable. A large number of developed countries such as Canada and many European countries have banking systems characterized by a small number of banks, but still produce competitive outcomes. 


\subsection{Empirical Results}

Table 10.8 reports the estimated results of equation (1) for our four models by using two-stage least squares (TSLS), where the second stage adopts weighted least squares (WLS). ${ }^{18}$ Table 10.9 reports the estimated results of equation (2). The TSLS procedure is applied to remove the endogenous effects so as to yield consistent estimates. The WLS is employed to take into account the heteroskedasticity problem. The weights of the WLS are the institution and residual squared, but only the former is reported.

In table 10.8 , the estimated coefficient of our liberalization variable COMMITTOBANK in Model (A) is insignificantly positive, suggesting that a country which commits to bank opening does not increase the growth of GDP per capita. The controlled variables emerge with the expected sign, though not always with significant coefficients. The most robust variables in this regard are $P C G D P 90$ (the initial per capita GDP), which is overwhelmingly significantly negative, indicating that the higher the initial income, the lower the growth. This is consistent with the income convergence theory (Barro and Sala-i-Martin 2004). The term INSTITUTION, which is the indicator of the general conditions regarding corruption, law and order, and bureaucratic quality, appears to be significantly positive in all specifications, suggesting that good governance enhances economic growth. Our measures of financial sector competition, CONCENTRATION, consistently emerge with a significantly negative sign. This should not be surprising because Demirgüç-Kunt and Levine (2001) also find that the correlation coefficient between the concentration ratio and growth is almost zero. The term CREDIT is overwhelmingly insignificant, which is partly similar to the findings in Shen and Lee (2006). ${ }^{19}$

Model (B) does not consider the liberalization and mainly examines the indirect effect of COMMITTOBANK through the CONCENTRATION. Thus, the focus is on the coefficient of CONCENTRATION reported in table 10.8 and the coefficient of COMMITTOBANK in equation (2) reported in table 10.9. The coefficient of CONCENTRATION in table 10.8 is equal to -0.0447 and is significant, suggesting that the higher the ratio, the lower the growth. Because the coefficient of COMMITTOBANK in table 10.9 is -15.1629 and is significant, we do find an indirect effect that the liberalization of the banking industry decreases the concentration ratio, which then increases the growth.

When the square of COMMITTOALL is added, as shown in Model (C), the estimated coefficients of COMMITTOALL and COMMITTOALL ${ }^{2}$

18. Our TSLS approach uses all exogenous variables to first predict the CONCENTRATION. The resulting predicted variables secondly replace the actual variables. The WLS simply uses the variable INSTITUTION as the weight to minimize the effect of the heteroskedasticity.

19. The coefficients of CREDIT in their regression are either insignificant or negative. 
The GDP per capita growth equation: Equation (1) of four models

\begin{tabular}{|c|c|c|c|c|c|}
\hline Independent Variables & Model A & Model B & Model C & Model D & Model D \\
\hline CONSTANT & $\begin{array}{r}1.6559 \\
(1.589)\end{array}$ & $\begin{array}{l}1.7604^{* * * *} \\
(1.651)\end{array}$ & $\begin{array}{r}0.4187 \\
(0.287)\end{array}$ & $\begin{array}{l}-2.8994 * * \\
(-2.245)\end{array}$ & $\begin{array}{l}-2.0923 \\
(-1.518)\end{array}$ \\
\hline СОМMITTOBANK & $\begin{array}{r}0.3051 \\
(0.336)\end{array}$ & & & $\begin{array}{l}8.4426^{*} \\
(2.620)\end{array}$ & $\begin{array}{l}8.1972 * * \\
(2.556)\end{array}$ \\
\hline COMMITTOALL & & & $\begin{array}{l}-5.3429 * * * \\
(-1.939)\end{array}$ & & \\
\hline COMMITTOALL $L^{2}$ & & & $\begin{array}{l}5.5680^{* *} \\
(2.285)\end{array}$ & & \\
\hline $\begin{array}{c}\text { COMMITTOBANK } \times \\
\text { SUPERVISION }\end{array}$ & & & & $\begin{array}{r}0.0535 \\
(0.594)\end{array}$ & $\begin{array}{r}0.0437 \\
(0.467)\end{array}$ \\
\hline $\begin{array}{l}\text { COMMITTOBANK } \times \\
\text { PRIVATE MONITOR }\end{array}$ & & & & $\begin{array}{l}-0.1337 \\
(-0.517)\end{array}$ & $\begin{array}{r}0.0142 \\
(0.057)\end{array}$ \\
\hline $\begin{array}{c}\text { COMMITTOBANK } \times \\
\text { CAPITALREGU }\end{array}$ & & & & $\begin{array}{l}-0.2442^{* *} \\
(-2.406)\end{array}$ & $\begin{array}{l}-0.2275^{* *} \\
(-2.349)\end{array}$ \\
\hline $\begin{array}{l}\text { COMMITTOBANK } \times \\
\text { GOVEFFECT }\end{array}$ & & & & $\begin{array}{l}0.5968^{* * *} \\
(1.699)\end{array}$ & $\begin{array}{l}0.6125^{* * *} \\
(1.820)\end{array}$ \\
\hline $\begin{array}{l}\text { COMMITTOBANK } \\
\text { INSTITUTION }\end{array}$ & & & & $\begin{array}{l}-0.7341^{*} \\
(-3.252)\end{array}$ & $\begin{array}{l}-0.7754^{*} \\
(-3.372)\end{array}$ \\
\hline $\begin{array}{l}\text { COMMITTOBANK } \times \\
\quad \text { EASIA }\end{array}$ & & & & & $\begin{array}{l}-0.5974 \\
(-1.257)\end{array}$ \\
\hline $\begin{array}{l}\text { COMMITTOBANK } \times \\
\quad \text { LATIN }\end{array}$ & & & & & $\begin{array}{l}-2.2099^{*} \\
(-3.806)\end{array}$ \\
\hline $\begin{array}{l}\text { COMMITTOBANK } \times \\
\text { SAHARAN }\end{array}$ & & & & & $\begin{array}{l}-2.7684^{* * *} \\
(-1.913)\end{array}$ \\
\hline CONCENTRATION & $\begin{array}{l}-0.0458^{*} \\
(-2.605)\end{array}$ & $\begin{array}{l}-0.0447 * * \\
(-2.459)\end{array}$ & $\begin{array}{l}-0.0514^{*} \\
(-2.755)\end{array}$ & $\begin{array}{l}-0.0116 \\
(-0.778)\end{array}$ & $\begin{array}{l}-0.0087 \\
(-0.598)\end{array}$ \\
\hline CREDIT & $\begin{array}{c}0.0014 \\
(1.206)\end{array}$ & $\begin{array}{l}0.0012 \\
(0.914)\end{array}$ & $\begin{array}{l}-0.00003 \\
(-0.022)\end{array}$ & $\begin{array}{r}0.0011 \\
(1.056)\end{array}$ & $\begin{array}{l}0.0007 \\
(0.659)\end{array}$ \\
\hline$T R A D E$ & $\begin{array}{l}0.0055^{* *} \\
(2.096)\end{array}$ & $\begin{array}{l}0.0054^{* *} \\
(1.971)\end{array}$ & $\begin{array}{l}0.0053^{* *} \\
(2.154)\end{array}$ & $\begin{array}{l}-0.0005 \\
(-0.176)\end{array}$ & $\begin{array}{l}-0.0012 \\
(-0.426)\end{array}$ \\
\hline STDINFLA & $\begin{array}{l}-0.0022 \\
(-1.105)\end{array}$ & $\begin{array}{l}-0.0022 \\
(-1.065)\end{array}$ & $\begin{array}{l}-0.0011 \\
(-0.953)\end{array}$ & $\begin{array}{l}-0.0017 \\
(-1.231)\end{array}$ & $\begin{array}{l}-0.0013 \\
(-0.935)\end{array}$ \\
\hline$P C G D P 90$ & $\begin{array}{l}-0.0002^{*} \\
(-5.282)\end{array}$ & $\begin{array}{l}-0.0002^{*} \\
(-4.671)\end{array}$ & $\begin{array}{l}-0.0002^{*} \\
(-4.765)\end{array}$ & $\begin{array}{l}-0.0001^{*} \\
(-3.487)\end{array}$ & $\begin{array}{l}-0.0001^{*} \\
(-3.211)\end{array}$ \\
\hline SECOND90 & $\begin{array}{r}0.0090 \\
(1.424)\end{array}$ & $\begin{array}{c}0.0093 \\
(1.537)\end{array}$ & $\begin{array}{l}0.0176^{* *} \\
(2.105)\end{array}$ & $\begin{array}{c}0.0011 \\
(0.204)\end{array}$ & $\begin{array}{l}-0.00001 \\
(-0.003)\end{array}$ \\
\hline INSTITUTION & $\begin{array}{l}0.3771^{*} \\
(3.579)\end{array}$ & $\begin{array}{c}0.3729 * \\
(3.508)\end{array}$ & $\begin{array}{l}0.4170^{*} \\
(3.909)\end{array}$ & $\begin{array}{l}0.5397^{*} \\
(3.557)\end{array}$ & $\begin{array}{c}0.4644^{*} \\
(3.124)\end{array}$ \\
\hline POPGR & $\begin{array}{l}-0.9839^{*} \\
(-5.476)\end{array}$ & $\begin{array}{l}-1.0006^{*} \\
(-5.624)\end{array}$ & & $\begin{array}{l}-0.9169^{*} \\
(-5.312)\end{array}$ & $\begin{array}{l}-0.8209^{*} \\
(-4.866)\end{array}$ \\
\hline INVESTMENT & & & & $\begin{array}{l}0.1043^{*} \\
(2.595)\end{array}$ & $\begin{array}{l}0.1049^{*} \\
(2.583)\end{array}$ \\
\hline$R^{2}$ & 0.349 & 0.338 & 0.208 & 0.472 & 0.500 \\
\hline Number of observations & 138 & 138 & 141 & 130 & 130 \\
\hline
\end{tabular}

Notes: Heteroskedasticity-robust $t$-values are in parentheses; *, **, and *** denote significance at the $1 \%, 5 \%$, and $10 \%$ levels, respectively. The model is estimated by Two-Stage Least Squares (TSLS), while the second stage uses Weighted Least Squares (WLS) with the weight being equal to institution. 
Table 10.9

The bank concentration equation: concentration

\begin{tabular}{lccc}
\hline Independent Variables & Model A & Model B & Model D \\
\hline CONSTANT & $76.5271^{*}$ & $76.5271^{*}$ & $78.3417^{*}$ \\
COMMITTOBANK & $(17.530)$ & $(17.530)$ & $(17.898)$ \\
& $-15.1629^{* *}$ & $-15.1629^{* *}$ & $-17.4480^{* *}$ \\
SIZE & $(-2.109)$ & $(-2.109)$ & $(-2.496)$ \\
& $-1.5466^{*}$ & $-1.5466^{*}$ & $-1.5735^{*}$ \\
$R^{2}$ & $(-7.479)$ & $(-7.479)$ & $(-7.476)$ \\
Number of observations & 0.764 & 0.764 & 0.779 \\
\hline
\end{tabular}

Notes: Heteroskedasticity-robust $t$-values are in parentheses; $*, * *$, and *** denote significance at the $1 \%, 5 \%$, and $10 \%$ levels, respectively. The model is estimated by Weighted Least Squares (WLS) with the weight being equal to COMMITTOBANK.

are -5.3429 and 5.5680, respectively. Thus, the influence of overall financial liberalization that includes the insurance, banking, and other sectors on the growth of income takes the form of a U-shaped curve; it first decreases the growth of income and then increases it. As the commitments start to increase, the burden and costs raised by short-run adjustments from the industries decrease the growth rate. As more and more liberalization measures are introduced, however, competition will bring about longrun benefits and will raise the growth of income.

The fourth column of table 10.8 reports the estimated results using Model (D), which incorporates the interaction variables. The estimated coefficient of the liberalization variable COMMITTOBANK is significantly positive, implying that the liberalization of the banking sector can increase the growth. Furthermore, the coefficient of the interaction variable COMMITTOBANK $\times$ GOVEFFECT is significantly positive, suggesting that good government effectiveness and regulatory quality can enhance the liberalization effect. The coefficients of the interaction variables COMMITTOBANK $\times$ SUPERVISION and COMMITTOBANK $\times$ $P R I V A T E M O N I T O R$ are insignificant. To our surprise, though, the coefficients of COMMITTOBANK $\times$ CAPITALREGU and COMMITTO$B A N K \times I N S T I T U T I O N$ are small, and are significantly negative. Accordingly, the stringency of the requirements of capital regulations and a decrease in the corruption may lessen the effect of liberalization. Because the coefficient of COMMITTOBANK is much larger (8.4426) than those of the two interaction variables $(-0.2442$ and -0.7341$)$, the reduced effect is small, except for large CAPITALREGU and INSTITUTION. ${ }^{20}$

The last column of table 10.8 reports the estimated results when the re-

20. This negative effect may be due to the short-run pain and long-run gain as suggested by Kaminsky and Schmukler (2003). 
gional dummies are included. The coefficients of the COMMITTOBANK remain significantly positive, with the coefficient being equal to 8.1972 . The coefficients of the interaction variables between COMMITTOBANK and the three regional dummies, EASIA, LATIN and SAHARAN are overwhelmingly negative $(-0.5974,-2.2099$, and -2.768 , respectively). However, only the latter two are significant. Thus, liberalization indeed increases the growth, but this positive effect is lessened only when it is implemented in Latin America and the Sub-Saharan area.

Table 10.9 reports the estimated results of equation (2) for models (A), (B) and (D). The coefficients of COMMITTOBANK are significantly negative regardless of the models, suggesting that the country that commits to bank opening decreases the concentration ratio of the banking sector. This may be because once the restrictions and regulations of the banking market are lessened, the establishment of new banks becomes more common, which decreases the concentration ratio.

To sum up, these results with regard to financial sector competition and growth, which are taken together with the apparent link between competition and liberalization, point to the following pattern in the data. Open financial sectors are more competitive, and more competitive financial sectors are strongly correlated with higher growth rates. Hence, through procompetitive effects, trade in financial services may enhance growth rates.

\subsection{Discussion and Concluding Remarks}

This chapter constructs a new financial liberalization index and then examines the impact of liberalization on economic growth. Although our chapter focuses on the liberalization of the trade in services (finance) sector, it is interesting to discuss the link between trade in services liberalization and trade in the goods sector first. Mattoo, Rathindran, and Subramanian (2006), for example, conclude that services liberalization differs from trade in goods because the former involves factor mobility and leads to scale effects that are distinctive, though not unique. Goods liberalization in the absence of services liberalization could well result in negative effective protection of goods, thus highlighting the need for the latter to keep pace with the former. Deardorff (2001) even stresses that the service liberalization can improve the trade liberalization. He examines the role played by services liberalization and finds that it can stimulate the trade not only in services, but also in goods. In particular, international trade in goods requires inputs from trade in services, too. Restrictions on movements in services across borders add costs and barriers to international trade in goods. Liberalizing trade in services could thus facilitate trade in goods.

Our new financial liberalization index is constructed based on the WTO commitment schedules of ninety-three countries in relation to financial services, and covers the 1994-2006 period. In the analysis we introduce several revisions, based on the method adopted by Hoekman $(1995,1996)$, 
to calculate the financial liberalization indices. These revisions include the covering mode 4 and all subsectors listed in the Annex on Financial Services, the weighting assigned to each of the four modes, and further scoring for partial commitments.

Our results show that the degree of liberalization is positively correlated with income level under modes 1,2 , and 3 , but not mode 4 . The liberalization index has a higher degree of correlation with the total trade balance than with the net trade balance, regardless of the subsectors. The correlation between the liberalization index and both trade balances, respectively, is raised when only mode 1 and mode 2 are covered in the liberalization index, probably because the existing statistics for the trade in services from the IMF only cover the trading volume under mode 1 and mode 2 . In addition, the liberalization in relation to market access and to national treatment is highly correlated. Also, a member country with a high degree of liberalization in one of these two subsectors tends to also have a high degree of liberalization in the other subsector.

We also find that East Asia and the Pacific and Latin America and the Caribbean are liberalized under mode 3 the most, whereas European and Central Asian and North American countries have chosen to liberalize less under mode 3 as compared with mode 1 and mode 2. East Asia and Pacific, and Latin America and Caribbean regions comprise many developing countries, which traditionally attract experienced foreign financial institutions through foreign direct investment (i.e., mode 3) in order to help develop their own domestic financial industries. By liberalizing under mode 3, which enables countries to attract incoming foreign direct investment, these countries not only enhance their industrial development and technology transfer, but they also increase their domestic employment in these areas.

Once the index is constructed, regression analyses are employed to investigate the direct and indirect effects of the liberalization on growth, where the indirect effect is examined through the concentration ratio of banks in each country. Furthermore, we examine whether the direct effect is affected by the governance variable in a broad sense and based on the regional variables. Our results show that the liberalization of the banking sector does directly enhance growth when all variables are included; however, it is only slightly sensitive to the model's specifications. The indirect effect also exists since the liberalization is found to negatively affect concentration, which will then negatively affect the growth.

Turning to the case of governance, the results also show that good government effectiveness and regulatory quality can enhance the liberalization effect. In addition, the stringency of the requirements of capital regulations and a decrease in corruption may lessen the effect of liberalization, although the effect is small. With respect to the regional effect, liberalization indeed increases the growth in East Asia, but this positive effect is lessened only when it is implemented in Latin America and the Sub-Saharan area. 


\section{Appendix}

Table 10A.1

The GDP per capita growth equation: Equation (1) of four models

\begin{tabular}{|c|c|c|c|c|c|}
\hline Independent Variables & $\begin{array}{l}\text { Model A } \\
\text { (TSLS) }\end{array}$ & $\begin{array}{l}\text { Model B } \\
\text { (TSLS) }\end{array}$ & $\begin{array}{l}\text { Model C } \\
\text { (TSLS) }\end{array}$ & $\begin{array}{l}\text { Model D } \\
\text { (TSLS) }\end{array}$ & $\begin{array}{l}\text { Model D } \\
\text { (TSLS) }\end{array}$ \\
\hline CONSTANT & $\begin{array}{l}1.8685^{* * *} \\
(1.739)\end{array}$ & $\begin{array}{l}1.8699^{* * *} \\
(1.780)\end{array}$ & $\begin{array}{r}0.7873 \\
(0.578)\end{array}$ & $\begin{array}{l}-2.4521 * * * \\
(-1.674)\end{array}$ & $\begin{array}{l}-1.6581 \\
(-1.075)\end{array}$ \\
\hline СОММITTOBANK & $\begin{array}{r}0.0035 \\
(0.004)\end{array}$ & & & $\begin{array}{l}7.0865^{* *} \\
(2.109)\end{array}$ & $\begin{array}{l}6.7332^{* *} \\
(2.000)\end{array}$ \\
\hline COMMITTOALL & & & $\begin{array}{l}-4.4379^{* * *} \\
(-1.677)\end{array}$ & & \\
\hline COMMITTOALL $L^{2}$ & & & $\begin{array}{l}4.2766^{* * *} \\
(1.920)\end{array}$ & & \\
\hline $\begin{array}{l}\text { COMMITTOBANK } \times \\
\text { SUPERVISION }\end{array}$ & & & & $\begin{array}{c}0.0266 \\
(0.297)\end{array}$ & $\begin{array}{r}0.0178 \\
(0.192)\end{array}$ \\
\hline $\begin{array}{l}\text { COMMITTOBANK } \times \\
\text { PRIVATEMONITOR }\end{array}$ & & & & -0.0614 & $\begin{array}{r}0.0704 \\
(0.293)\end{array}$ \\
\hline $\begin{array}{l}\text { PRIVATEMONITOR } \\
\text { COMMITTOBANK } \times\end{array}$ & & & & $\begin{array}{l}(-0.251) \\
-0.2485^{*}\end{array}$ & $\begin{array}{l}(0.293) \\
-0.2458^{*}\end{array}$ \\
\hline CAPITALREGU & & & & $(-2.580)$ & $(-2.580)$ \\
\hline $\begin{array}{l}\text { COMMITTOBANK } \times \\
\text { GOVEFFECT }\end{array}$ & & & & $\begin{array}{c}0.5088 \\
(1.442)\end{array}$ & $\begin{array}{r}0.4923 \\
(1.434)\end{array}$ \\
\hline $\begin{array}{l}\text { COMMITTOBANK } \times \\
\text { INSTITUTION }\end{array}$ & & & & $\begin{array}{l}-0.6025^{* *} \\
(-2.413)\end{array}$ & $\begin{array}{l}-0.6177 * * \\
(-2.447)\end{array}$ \\
\hline $\begin{array}{l}\text { COMMITTOBANK } \times \\
\quad \text { EASIA }\end{array}$ & & & & & $\begin{array}{l}-0.7996^{* * *} \\
(-1.769)\end{array}$ \\
\hline $\begin{array}{l}\text { COMMITTOBANK } \times \\
\text { LATIN }\end{array}$ & & & & & $\begin{array}{l}-2.1054^{*} \\
(-3.498)\end{array}$ \\
\hline $\begin{array}{l}\text { COMMITTOBANK } \times \\
\text { SAHARAN }\end{array}$ & & & & & $\begin{array}{l}-3.0113^{* *} \\
(-1.964)\end{array}$ \\
\hline CONCENTRATION & $\begin{array}{l}-0.0356^{* *} \\
(-2.548)\end{array}$ & $\begin{array}{l}-0.0356^{* *} \\
(-2.484)\end{array}$ & $\begin{array}{l}-0.0389^{*} \\
(-2.697)\end{array}$ & $\begin{array}{l}-0.0124 \\
(-0.854)\end{array}$ & $\begin{array}{l}-0.0108 \\
(-0.766)\end{array}$ \\
\hline CREDIT & $\begin{array}{c}0.0009 \\
(0.775)\end{array}$ & $\begin{array}{r}0.0009 \\
(0.741)\end{array}$ & $\begin{array}{l}-0.0006 \\
(-0.399)\end{array}$ & $\begin{array}{r}0.0011 \\
(1.021)\end{array}$ & $\begin{array}{r}0.0008 \\
(0.658)\end{array}$ \\
\hline$T R A D E$ & $\begin{array}{l}0.0054^{* *} \\
(2.068)\end{array}$ & $\begin{array}{l}0.0054^{* *} \\
(2.020)\end{array}$ & $\begin{array}{l}0.0047^{* * *} \\
(1.955)\end{array}$ & $\begin{array}{c}0.0006 \\
(0.218)\end{array}$ & $\begin{array}{r}0.0001 \\
(0.019)\end{array}$ \\
\hline STDINFLA & $\begin{array}{l}-0.0024 \\
(-1.120)\end{array}$ & $\begin{array}{l}-0.0024 \\
(-1.079)\end{array}$ & $\begin{array}{l}-0.0014 \\
(-1.093)\end{array}$ & $\begin{array}{l}-0.0017 \\
(-1.190)\end{array}$ & $\begin{array}{l}-0.0015 \\
(-0.949)\end{array}$ \\
\hline PCGDP90 & $\begin{array}{l}-0.0002^{*} \\
(-5.307)\end{array}$ & $\begin{array}{l}-0.0002^{*} \\
(-4.870)\end{array}$ & $\begin{array}{l}-0.0002^{*} \\
(-4.997)\end{array}$ & $\begin{array}{l}-0.0001^{*} \\
(-3.356)\end{array}$ & $\begin{array}{l}-0.0001^{*} \\
(-3.068)\end{array}$ \\
\hline SECOND90 & $\begin{array}{r}0.0060 \\
(1.028)\end{array}$ & $\begin{array}{r}0.0060 \\
(1.073)\end{array}$ & $\begin{array}{l}0.0131^{* * *} \\
(1.763)\end{array}$ & $\begin{array}{r}0.0002 \\
(0.042)\end{array}$ & $\begin{array}{l}-0.0010 \\
(-0.209)\end{array}$ \\
\hline INSTITUTION & $\begin{array}{l}0.3372^{*} \\
(3.647)\end{array}$ & $\begin{array}{l}0.3372^{*} \\
(3.692)\end{array}$ & $\begin{array}{l}0.3641^{*} \\
(3.935)\end{array}$ & $\begin{array}{l}0.4761^{*} \\
(2.891)\end{array}$ & $\begin{array}{l}0.4087^{* *} \\
(2.564)\end{array}$ \\
\hline POPGR & $\begin{array}{l}-0.8936^{*} \\
(-5.090)\end{array}$ & $\begin{array}{l}-0.8938^{*} \\
(-5.291)\end{array}$ & & $\begin{array}{l}-0.8556^{*} \\
(-5.061)\end{array}$ & $\begin{array}{l}-0.7660 * \\
(-4.555)\end{array}$ \\
\hline INVESTMENT & & & & $\begin{array}{l}0.1109^{*} \\
(2.803)\end{array}$ & $\begin{array}{c}0.1147^{*} \\
(2.811)\end{array}$ \\
\hline$R^{2}$ & 0.301 & 0.298 & 0.174 & 0.424 & 0.447 \\
\hline Number of observations & 138 & 138 & 141 & 130 & 130 \\
\hline
\end{tabular}

Notes: Heteroskedasticity-robust t-values are in parentheses; ${ }^{* *}$, and $* * *$ denote significance at the $1 \%, 5 \%$, and $10 \%$ levels, respectively. The model is estimated by Two-Stage Least Squares (TSLS). 
Table 10A.2

The bank concentration equation: CONCENTRATION

\begin{tabular}{lccc}
\hline Independent Variables & Model A & Model B & Model D \\
\hline CONSTANT & $68.1093^{*}$ & $68.1093^{*}$ & $69.6667^{*}$ \\
COMMITTOBANK & $(17.544)$ & $(17.544)$ & $(17.798)$ \\
& -0.5034 & -0.5034 & -2.6828 \\
SIZE & $(-0.081)$ & $(-0.081)$ & $(-0.437)$ \\
& $-1.5759^{*}$ & $-1.5759^{*}$ & $-1.5833^{*}$ \\
$R^{2}$ & $(-7.225)$ & $(-7.225)$ & $(-7.332)$ \\
Number of observations & 0.112 & 0.112 & 0.120 \\
\hline
\end{tabular}

Notes: Heteroskedasticity-robust t-values are in parentheses; $*, * *$, and $* * *$ denote significance at the $1 \%, 5 \%$, and $10 \%$ levels, respectively. The model is estimated by OLS.

\section{References}

Barro, R., and X. Sala-i-Martin. 2004. Economic Growth, 2nd ed. Cambridge, MA: MIT Press.

Barth, J., G. Caprio, Jr., and R. Levine. 2001. The regulation and supervision of banks around the world: A new database. Policy Research Working Paper no. 2588. Washington, DC: World Bank.

Barth, J., G. Caprio, Jr., and R. Levine. 2006. Rethinking bank regulation: Till angels govern. Cambridge, England: Cambridge University Press.

Beck, T., A. Demirgüç-Kunt, and R. Levine. 2000. A new database on financial development and structure. World Bank Economic Review 14:597-605.

Bekaer, G., and C. R. Harvey. 2000. Foreign speculators and emerging equity markets. Journal of Finance 55 (2): 565-613.

Bosworth, M., C. Findlay, R. Trewin, and T. Warren. 2000. Price-impact measures of impediments to services trade. In Impediments to trade in services: Measurement and policy implications, ed. C. Findlay and T. Warren, 42-51. London: Routledge.

Claessens, S., A. Demirgüç-Kunt, and H. Huizinga. 2001. How does foreign entry affect domestic banking markets? Journal of Banking and Finance 25:891-911.

Claessens, S., and T. Glaessner. 1998. The internationalization of financial services in Asia. Policy Research Working Paper no. 1911. Washington, DC: World Bank.

Deardorff, A. V. 2001. International provision of trade services, trade, and fragmentation. Review of International Economics 9 (2): 233-48.

Demirgüç-Kunt, A., and E. Detragiache. 1998. The determinants of banking crises in developing and developed countries. IMF Staff Papers 45 (1): 81-109.

Demirgüç-Kunt, A., and E. Detragiache. 2001. Financial liberalization and financial fragility. In Financial liberalization: How far, how fast?, eds. G. Caprio, P. Honahan, and J. E. Stiglitz, 96-124. Cambridge, England: Cambridge University Press.

Demirgüç-Kunt, A., and R. Levine. 2001. Bank-based and market-based financial systems: Cross-country comparisons. In Financial structure and economic growth: A cross-country comparison of banks, markets, and development, eds. A. Demirgüç-Kunt and R. Levine, 81-140. Cambridge, MA: MIT Press.

Eschenbach, F., J. F. Francois, and L. Schuknecht. 2000. Financial sector openness 
and economic growth. In The internationalization of financial services: Issues and lessons for developing countries, eds. S. Claessens and J. Jansen, 103-15. London: Kluwer Law International.

Francois, J. F., and L. Schuknecht. 1999. Trade in financial services: Procompetitive effects and growth performance. CEPR Discussion Paper no. 2144. London: Centre for Economic Policy Research.

Henry, P. 2000. Do stock market liberalizations cause investment booms? Journal of Financial Economics 58:301-34.

Hoekman, B. 1995. Tentative first step: An assessment of the Uruguay round agreement on services. Policy Research Working Paper no. 1455. World Bank.

Hoekman, B. 1996. Assessing the general agreement on trade in services. In The Uruguay Round and the Developing Countries, eds. W. Martin and L. A. Winters, 88-124. Cambridge, England: Cambridge University Press.

Hoekman, B., and C. A. Primo Braga. 1997. Protection and trade in services: A survey. Open Economies Review 8:285-308.

Kaminsky, G. L., and C. M. Reinhart. 2002. Financial markets in times of stress. Journal of Development Economics 69 (2): 451-70.

Kaminsky, G. L., and S. L. Schmukler. 2003. Short-run pain, long-run gain: The effects of financial liberalization. IMF Working Paper no. 03/34. World Trade Organization.

Kaufmann, D., A. Kraay, and M. Mastruzzi. 2005. Governance matters IV: Governance indicators for 1996-2004. Draft. World Bank.

Kawakatsu, H., and M. R. Morey. 1999. An empirical examination of financial liberalization and the efficiency of emerging market stock prices. Journal of Financial Research 4:385-411.

Levine, R., and S. Zervos. 1998. Stock market, banks and economic growth. American Economic Review 88 (3): 537-58.

Mattoo, A. 1998. Financial services and the WTO: Liberalization in the developing and transition economies. Staff Working Paper no. TISD9803. World Trade Organization.

Mattoo, A. 2000. Financial services and the WTO: Liberalization commitments of the developing and transition economies. World Economy 23 (3): 351-86.

Mattoo, A., R. Rathindran, and A. Subramanian. 2006. Measuring services trade liberalization and its impact on economic growth: An illustration. Journal of Economic Integration 21:64-98.

Maurer, A. 2005. Economic importance of cross-border trade in services-Recent developments. Symposium on the Cross-border Supply of Services, 28-29 April 2005, Geneva: World Trade Organization.

McGuire, G., and M. Schuele. 2000. Restrictiveness of international trade in banking services. In Impediments to trade in services: Measurement and policy implications, eds. C. Findlay and T. Warren, 172-88. London: Routledge.

Montes-Negret, F., and L. Landa. 2001. Interest rate spreads in Mexico during liberalization. In Financial liberalization: How far, how fast? eds. G. Caprio, P. Honohan, and J. E. Stiglitz, 188-207. Cambridge, England: Cambridge University Press.

PECC. 1995. Survey of impediments to trade and investment in the APEC region. Pacific Economic Cooperation Council.

PECC International Secretariat. 2003. Financial services liberalization and its sequencing in the APEC region: WTO and RTAS. Pacific Economic Cooperation Council.

Qian, Y. 2000. Financial services liberalization and GATS. In The internationalization of financial services: Issues and lessons for developing countries, eds. S. Claessens and M. Jansen, 63-101. London: Kluwer Law International. 
Shen, C. H., and C. C. Lee. 2006. Same financial development yet different economic growth - Why? Journal of Money, Credit, and Banking 38 (7): 1907-44.

Tornell, A., F. Westermann, and L. Martinez. 2004. The positive link between financial liberalization growth and crises. NBER Working Paper no. 10293. Cambridge, MA: National Bureau of Economic Research.

Valckx, N. 2002. WTO financial services liberalization: Measurement, choice and impact on financial stability. Research Memorandum Wo no. 705. De Nederlandsche Bank.

\section{Comment Shin-ichi Fukuda}

The motivation of this chapter is to explore the relationship between liberalization of financial services and economic growth by cross-country regression. There are several previous studies that have explored the same issue. But how to measure the depth and growth of financial markets is very controversial in these studies. There are some measures of the depth and growth of financial markets in literature: liquid liabilities and gross claims on the private sector in King and Levine (1993), private sector credit in De Gregorio and Guidotti (1995), real interest rate distortions and lendingdeposit spread in Roubini and Sala-i-Martin (1992), and stock market activities in Levine and Zervos (1998). Problems with these measures are that they are endogenous variables. Causality was not necessarily clear in these studies. Some common factor may derive both financial development and growth. Financial development-typically measured by the level of credit and the size of the stock market - may predict economic growth simply because financial markets anticipate future growth.

What is new in this chapter is the use of measures on liberalization on international trade in financial services based on the GATS commitments in overall financial sectors. The measures may not be purely exogenous, but less endogenous than those in previous studies. By using the measures, the authors constructed an index to measure nontariff barriers and found a more clear and less biased link from financial liberalization to economic growth. The main result is a positive link between the liberalization of the financial sector and economic growth. But the link is indirect. The liberalization of the financial sector leads to more competition within the financial sector and this leads to higher economic growth. An implication of this chapter is that the liberalization of the financial sector is important because it makes the financial sector more competitive. The result seems plausible.

However, there are alternative views in the literature for the impacts of financial market liberalization: a positive view, a negative view, and a positive view with some reservations. A positive view, which is this chapter's 
view, includes Goldsmith (1969), McKinnon (1973), and King and Levine (1993). They assert that financial market liberalization will channel investment funds to their most productive uses so that it will enhance capital accumulation and promote economic growth. In contrast, a negative view, such as Stiglitz (2004), insists that the positive views are based on the neoclassical model with perfect information, perfect capital market, and perfect competition. Capital-market liberalization was systematically associated with instability in developing countries. Crises in East Asia and Latin America in recent decades are good examples for the instability. A positive view with some reservations asserts that the liberalization of foreign direct investment (FDI) has a positive effect on economic growth. But the liberalization of short-term capital flows does not. The economic crises of the late 1990s were attributable to worldwide capital-market liberalization of short-term capital flows in the 1980s and 1990s. Another positive view with some reservations proposes that we need some preconditions for successful capital-market liberalization, such as good corporate governance, transparent accounting rules, legal protections of investors, prudential regulation by government, some possible extensions, and so on. This chapter attempts to identify some of the channels through which capital-market liberalization leads to faster economic growth, but it does not seem to attempt to test the alternative hypothesis, including the positive views with some reservations. We need to include alternative measures in the regressions to test the alternative hypothesis. The use of some measures on capital-market liberalization of short-term capital flows may be desirable.

To check the robustness of the interesting findings, we call for further investigations in the chapter. In the growth regression, the index of financial liberalization becomes insignificant when concentration in the financial sector is included in the explanatory variables. The liberalization of the financial sector may not enhance economic growth unless it makes the financial sector more competitive. This is somewhat consistent with the positive view with some reservations. Model (C) finds that there is a nonlinear relationship between the index of financial liberalization and economic growth. The overall financial liberalization first has a negative impact on economic growth, and then the impact becomes positive. This finding may also be consistent with the alternative views. We probably need to add further deliberate interpretations, as well as further regressions, to the robustness.

The sample periods may be too short to discuss long-run economic growth. The chapter used the average growth rate for the periods 1994-2000 and 2001-2005. The average growth rate in the short sample periods may reflect short-run business cycles. In particular, a series of crises occurred during the sample periods. Ideally, we need longer sample periods.

We may also need to use alternative economic indicators in the regressions. Economic indicators that are included in standard growth regres- 
sions are initial income level, investment rates (or saving rates), population growth, and human capital. These variables are consistent with Solow's growth model (Mankiw, Romer, and Weil 1992). The chapter included most of them. But investment rates (or saving rates) are missing in this chapter. Investment rates are usually the most significant variable. In this chapter, the level of human capital is controlled by the secondary school enrollment ratio. But this is a flow data. Theoretically, it is more desirable to use some stock data of human capital such as accumulation of previous school enrollments (see Barro and Lee 1993).

\section{References}

Barro, R. J., and J. W. Lee. 1993. International comparisons of educational attainment. Journal of Monetary Economics 32 (3): 363-94.

De Gregorio, J., and P. E. Guidotti. 1995. Financial development and economic growth. World Development 23 (3): 433-48.

Goldsmith, R. W. 1969. Financial structure and development. New Haven, CT: Yale University Press.

King, R. G., and R. Levine. 1993. Finance and growth: Schumpeter might be right. Quarterly Journal of Economics 108 (3): 717-37.

Levine, R., and S. Zervos. 1998. Stock markets, banks, and economic growth. American Economic Review 88 (3): 537-58.

McKinnon, R. I. 1973. Money and capital in economic development. Washington, DC: Brookings Institution.

Mankiw, N. G., D. Romer, D. N. Weil. 1992. A contribution to the empirics of economic growth. Quarterly Journal of Economics 107 (2): 407-37.

Roubini, N., and S. Xavier. 1992. Financial repression and economic growth. Journal of Development Economics 39 (1): 5-30.

Stiglitz, J. E. 2004. Globalization and growth in emerging markets. Journal of Policy Modeling 25:465-84.

\section{Comment Roberto S. Mariano}

This chapter utilizes panel cross-country regressions, of the partial reduced-form type, to analyze the overall contribution of the financial sector to economic growth and the role of liberalization in the financial sector (as well as the competition within the sector) in this process. One main contribution of the chapter lies in the way in which financial liberalization is measured - namely, through the financial liberalization commitments of countries under the General Agreement on Trade in Services (GATS).

The financial sector liberalization index in the chapter is based on esti-

Roberto S. Mariano is a professor of economics and statistics, dean of the School of Economics, and Vice Provost for Research at Singapore Management University, and Professor Emeritus of Economics and Statistics at the University of Pennsylvania. 
mates of tariff-equivalents for trade in financial services utilizing GATS commitments within the WTO - as submitted by each member country within the periods 1994-2000 and 2001-2005. Two liberalization indices are constructed: one for all financial services (banking, insurance, and others) and one for banking alone. These indices are constructed through a disaggregate treatment of subsectors of financial services and the four possible modes of supply identified by GATS, with appropriate weighting of the four modes and with scoring for partial commitments, and in the context of market access and national treatment. The four modes of supply identified by GATS are cross-border supply, consumption abroad, commercial presence, and movement of natural persons.

Patterns of correlation of these liberalization indices with the trade balance for WTO members, and differences among these indices across geographical regions as well as income levels are described in the chapter. The empirical analysis in the chapter points to a "positive pattern linking the financial sector competition indicators with . . f financial sector liberalization, and economic growth with the financial sector competition." The positive effect is increased further when a government is effective and has good regulation. However, when a country has stringent requirements on capital regulation and decreased corruption, the positive effects of an open banking sector are lessened.

The authors go through a painstaking process of constructing their indices and they are to be commended for the detailed work and discussion of this process as well as their literature review and discussion of patterns of financial liberalization under the WTO. These are covered in the first three sections of the chapter. In their discussion, the authors allude to one possible major deficiency of their liberalization index — that is, being based on GATS commitments rather than on extent of liberalization that actually took place. It could very well be that these commitments are the best observable proxy for actual liberalization. But, the authors themselves point out that "subsequent unilateral liberalization undertaken by some members has widened the gap between GATS commitments and actual measures."

The fourth and fifth sections of the chapter deal with the empirics of financial liberalization and growth. In footnote 19, the authors comment that the variable CONCENTRATION is a misleading indicator of the level of competition in the banking system. If this is the case, why use this variable in the empirical exercise at all? The estimation results reported in tables 10.8 and 10.9 apparently are based on panel data for ninety-three countries for the two periods 1994-2000 and 2001-2005. I wonder how this number of ninety-three countries fits with the reported numbers of observations in tables 10.8 and 10.9 (between 130 and 141). It is good to see that the authors have included Model (D) in tables 10.8 and 10.9, which shows statistically significant interaction terms - such as the interaction of finan- 
cial liberalization in banks (COMMITTOBANK) with capital regulation (CAPITALREGU), government effectiveness (GOVEFFECT), and corruption (INSTITUTION). Regarding estimating procedure, as remarked by the authors in footnote 20 , the estimated equations in table 10.8 are obtained by a two-stage least squares procedure which uses all the exogenous variables to correct for the endogeneity of CONCENTRATION. In the second stage, weighted least squares is implemented by using INSTITUTION as the weight in the correction for heteroskedasticity. The authors need to re-examine this approach on various counts. Concerning the correction for heteroskedasticity, if INSTITUTION is categorical, (and this is not clear in the chapter), why not use estimated standard deviations in each INSTITUTION category as the weights?

As to the correction for endogeneity, some of the other regressors in the equation for growth in per capita GDP in Model (D) also may be endogenous, such as trade openness (TRADE), percent of credit to the private sector (CREDIT), standard deviation of inflation (STDINFLA), and financial liberalization itself (COMMITTOBANK). If so, these variables cannot be used as instruments in the first stage and, indeed, corrections for their endogeneity also should be made. 